\title{
JIHAD PENISTA AGAMA JIHAD NKRI: ANTONIO GRAMSCI'S HEGEMONY THEORY ANALYSIS OF RADICAL DA'WAH PHENOMENA IN ONLINE MEDIA
}

\author{
Fatmawati $^{1}$ \\ UIN Syarif Hidayatullah Jakarta \\ E-mail: fatmawati@uinjkt.ac.id \\ Kalsum Minangsih \\ UIN Syarif Hidayatullah Jakarta \\ E-mail: kalsumminangsih@uinjkt.ac.id \\ Siti Mahmudah Noorhayati \\ Institut Agama Islam Sahid Bogor \\ E-mail: noorhayatimahmudah@gmail.com
}

\begin{abstract}
This article explores the new trends of Islamic radicalism through missionary jihad against a blasphemer (Ahok) as part of the jihad for the NKRI (Unitary State of the Republic of Indonesia). The trend of radical dakwah in online media is interesting to research, regardless of the interest of the local election, or Caliphate and NKRI sharia on the other hand. The purpose of this research is to find out the trend of radical dakwah in online media by calling jihad against a blasphemer as part of the NKRI jihad and its implication. The questions in this study will be examined using the theory of domination of interests (hegemony), given the position of the radicals is to seize the hegemony of society through online viral media. In conclusion, the use of the term Jihad against a blasphemer, and political branding that radical groups still maintain the integrity of the NKRI is a hegemonic form to defeat the cultural power of the moderate, tolerant, and plural Muslims. These radicals, together with the intellectual actors behind them, realize that in order to gain legitimacy of religious power, they must collaborate with the MUI (fatwa institution), then use social media to invite all to participate to do counter discourse. After that, they collaborated with politicians to advocate the idea they propose. Finally, they use symbolic Islamic slogans to bring Muslims to the struggle that they do.
\end{abstract}

Keywords : Blasphemer, Hegemonic Jihad, Radicalism

${ }^{1}$ The authors would like to record special appreciation and credit to the funding support for the research project. This research was possibly accomplished with the financial support by the BOPTN DIPA UIN Syarif Hidayatullah Jakarta fund through the Decision of the Budget User of UIN Syarif Hidayatullah Jakarta Number: Un.01/ KPA/569/2017 concerning Recipients of Financing for Research at the UIN Syarif Hidayatullah Jakarta 2017 Fiscal Year, Research Cluster of Development of Islamic Studies on 25 July 2017. 


\section{INTRODUCTION}

It was Tuesday, 27 September 2016 when a story began. A speech delivered by the Jakarta Governor, Basuki Cahaya Purnama or often called Ahok during his visit to the Pramuka Island of Seribu Islands is considered to be blasphemy. In his visit to the cultivation program funded by the Provincial Government of Jakarta, Ahok mentioned Surat al-Maidah verse 51 as one of the verses used to "deceive" the public. Nine days after this speech was delivered, precisely on 6 October 2016, a video recording of Ahok's speech was uploaded via Buni Yani's Facebook account entitled "Blasphemy against Religion?" With Ahok's speech transcription. Ahok's speech on Seribu Islands left many problems in the future. Reports and complaints to the police came in a row, both from FPI and MUI, participating as the reporter. ${ }^{2}$ Various media outlets responded to Ahok >s viral speech as hot news from the capital city of Jakarta. It even became national scale news delivered to the Indonesian people from Sabang to Merauke, although Ahok has offered his apology to the public. ${ }^{3}$

Viral online media about blasphemy led to mass mobilization of Muslims, the Islamic community movement 411, the Muslim movement 212, to the Muslim movement 505 who are radical and intolerant. Mobilization and call for radical dakwah through the moment and event of the Islamic movement is inseparable from the role of online media, both news and social media such as Twitter, Facebook, YouTube, blogs or Whatsapp applications by blowing up the case massively as a radical propaganda to attract the sympathy of Muslims. In this case, Tri Pujiati considered that social media propaganda was used as a useful means of radical dakwah. Openly, the propaganda was carried out to recruit as many people as possible face to face. As a result, a large number of victims were those in their teens who in fact were active users of social media. The age range of 15-25 years is vulnerable and easily influenced and swayed to show self existence. ${ }^{4}$

Nafi Muthohirin argued that in the second decade of the 21st century there appeared the tendency of radical groups to increase their interaction

${ }^{2}$ Ismantoro Dwi Yuwono, Gara-Gara Ahok dari Kegaduhan ke Kegaduhan (Yogyakarta: Media Pressindo, 2017), 311-314; for further reference, see also Abdul Malik, "Agitasi dan Propaganda di Media Sosial (Studi Kasus Cyberwar Antar-Netizen terkait Dugaan Penistaan Agama oleh Basuki Tjahaja Purnama)," Jurnal Lontar, Vol 4 No 3 (September - Desember 2016), 7-8.

${ }^{3}$ Ahmad Junaidi, "Media dan Keberagaman: Analisis Pemberitaan Media Daring Seputar Pemilihan Kepala Daerah DKI Jakarta," Jurnal Muara Ilmu Sosial, Humaniora, dan Seni, (Vol. 1, No. 1, April 2017), 330-334.

${ }^{4}$ Tri Pujiati, "Dakwah Radikal dan Propaganda Media Sosial," in http://jalandamai. org/dakwah-radikal-dan-propaganda-media-sosial.html 
and propaganda. They make certain pages to spread ideas and hate, radicalism, threats, and provide tutorial on how to make bombs. A number of websites have their identities hidden with unknown encryption technology tools. Even with such tight control, radical groups can still find their way and continue to use anonymous accounts. The use of pictorial memes containing radical messages is also created in order to attract the sympathy of young people. Then, consistently and creatively, the meme images are posted and shared on Facebook, Twitter, Instagram, and WhatsApp reaching thousands of netizens in a short time. ${ }^{5}$

Radical dakwah in online media regarding Ahok's speech on the Pramuka Island of the Thousand Islands gave a real picture of the radical resistance movement to the existing situation. Even the slogans and jargons that have always been the source of online media struggle by radicals call for dakwah to carry out jihad against the blasphemer as part of the NKRI jihad. The slogan that is always echoed is: "Ready for jihad? Ready to defend the country, ready to defend Islam, ready to defend NKRI (the Unitary State of the Republic of Indonesia?)." ${ }^{6}$ This slogan became a hash-tag on various social media by always referring to Ahok as "the blasphemer" of ethnic Chinese who has disturbed the harmony and sovereignty of Muslims in the Republic of Indonesia. Even the radicals have publicly stated that Ahok is the threat that divides the tribes and nations and the Unitary State of the Republic of Indonesia is under threat and expansion of the Chinese State. ${ }^{7}$

With regard to the various polemics and discourses, this will give birth to a hypothesis that the hashtags of jihad against the blasphemer, jihad NKRI became a propaganda trend for radicals in some online media that are always viral in the last period in this country. All radical propaganda, issues and movements have made the speech of "the blasphemer" the beginning of resistance (jihad) which bring diverse responses and analyses. Is it for the sake of DKI Jakarta elections on the one hand, or for the interest of the Caliphate and NKRI in sharia on the other. In this light, it is interesting to carry out this research.

${ }^{5}$ Nafi Muthohirin, "Mewaspadai Radikalisme Islam di Media Sosial," in http://geotimes.co.id/mewaspadai-radikalisme-islam-di-media-sosial/

${ }^{6}$ The call for jihad bela NKRI is first launched by Habib Rizieq acting as the Imam Besar Front Pembela Islam in the middle of the crowd for his special speech in for the Forum Umat Islam (FUI) members and supporters doing protest vigil in front of the house of parliament (Gedung DPR RI). The related news about the FPI and radical movement organizations with the slogan of Jihad NKRI can be read here http://nasional.kini.co.id/2017/02/21/20880/ habib-rizieq-ajak-massa-jihad-bela-negara-bela-islam-dan-nkri

${ }^{7}$ The statement by radicalism movements can be found here https://www.youtube. com/watch?v=1AlkdqIpLi0 
To frame this research as a scientific product, there are two aspects that the writer focus on. Why did the radical dakwah trend occur in online media by calling on jihad against the blasphemer as part of the NKRI jihad? What are the implications of the radical dakwah trend in online media by calling on jihad against the blasphemer as part of NKRI jihad? Two focus issues will be explored using the qualitative research method and Antonio Gramsci's theory will be used as a perspective framework of the phenomenon. In addition, the author will also limit the phenomenon of jihad against the blasphemer in the Jakarta local elections because the issue of blasphemy and the anarchic behavior of radical groups against others is often seen not only in the momentum of the Local Elections.

\section{ISLAMIC RADICALISM IN MEDIA CONSIDERATION}

It was the dictum After 9/11 2001 tragedy, which became the beginning of Islam, radicalism, and terrorism to be re-discussed; whether it is academic discourse, mass media and electronics, or ethnographic translation discussed by people in their respective environments. J. Esposito said that this 9/11 2001 tragedy was a global shock and had a poorly perceptual impact on Islam itself. Moreover, this call for resistance to Islam was carried out by a president of a superpower like America. J. Esposito revealed:

"For many, understanding Islam and Muslims can be confusing. Muslim leaders speak of Islam as a religion of peace and justice; Osama bin Laden and other Muslim terrorists slaughter non-Muslims and Muslims globally. President George W. Bush referred to Islam as a religion of peace; the Franklin Graham evangelist called Islam an evil religion; Samuel Huntington, prominent Harvard professor and author of The Clash of Civilizations, wrote, 'Islam has bloody borders. . . and innards. " But, as President Barrack Obama has pointed out, "Islam has demonstrated through words and the possibilities of religious tolerance and racial equality.... Partnership between America and Islam must be based on what Islam is, not what it isn't."

The ambiguity of this diverse definition of Islam finally presented the religion in various new 'logos'. Radical Islam, fundamental Islam, liberal Islam, moderate Islam, and inclusive Islam. All of these logos have an impact on the choice of attitudes of Muslims in the world including in Indonesia. Today, when discussing Indonesia's Islam, it cannot be completed in the space of moderation of the two major powers of Islamic organizations (Nahdlatul

${ }^{8}$ J. Esposito, The Future Of Islam, (New York : Oxford University Press, 2010), 01 
Ulama and Muhammadiyah). In Indonesia, many Islamic variants have been reduced rather than ways of thinking, acting, and they are associated with one another.

The discourse variants related to the Islamic attitudes above are inseparable from the global concessions, especially the tragedy in the reform era (burning of Christian houses of worship in some areas) and the Bali bombing tragedy in 2002. At that time, the contestation of Islamism (read: Islamic ideals and attitudes, not Islamic ideology) are again discussed in the public space. There are many intellectual actors who will return the Islamic discourse in that era. Among those who represent moderate groups are Abdurrahman Wahid, Nur Chalis Madjid, as well as Nahdlatul Ulama and Muhammadiyah Muslim scholars. The liberal group is represented by Ulil Abshar Abdallah, Lutfi A., Muqsith Ghazali, and those who are gathered in the Jakarta Utan Kayu Community. On the other side, there are Isamail Yusanto, Hatono Ahmad Jaiz, and Addian Husaeni, intellectual groups who are more conservative in their thought. On the movement side, names such as Abdullah Sungkar, Abu Bakar Baasyir, and Imam Samudera, were represented by the Jemaah Islamiyah movement group which in the Soeharto era was alienated due to rebellion to establish an Islamic state in Indonesia. ${ }^{9}$ Because of the length of the debate on Islamism and the attitudes of nationalism in Indonesia, all of them have been recorded by academics to read the current phenomena. So this study focuses on two important aspects: first, reframing the contestation of Islamic radicalism and religio-nationalism in the online media in recent years, particularly in the past ten years. Of course by making representation of the two groups that have debated on how to present Islam in Indonesia. Second, the shift of radical groups in campaigning their radical ideas through radical group organization websites, social media, and several articles submitted to Islamic nuance newspaper like Republika.

At the beginning of the reform, access to information and radical ideas was not as easy as it is today. Transmission of information related to radicalism, its tendency, can only be accessed through print reporting, very rarely based on online networking. Therefore, this paper will seek to discuss the discourse on Islamic radicalism in media coverage, and patterns of change. The first period, in the 2001-2005 era, where the contestation of Islamic ideas took place in a narrow space especially in the newspaper information booth. The second period, 2005-2010, internet-based information access has begun to spread in Indonesia. The internet could even be accessed by the village community, although it is still based on internet provider stalls. In the same

${ }^{9}$ Din Wahid, “Kembalinya Konservatisme Islam Indonesia," Studia Islamika, (Vol. 21 No. 2 2014), 387. 
year, social media has also begun to be in demand by the community as an alternative media to get the latest information. Finally, in the period of 2010 to present, where access to information is already in the grip of a smart phone, the community involvement in social media has become more active than before. This is coupled with the existence of news television station which has become the dominant source of information in the community. Borrowing the terminology in the media center of political actors, today is the era of generation $\mathrm{Z}$, the generation that understands and wants to always be involved in every activity of (digital) virtual life.

In this early period, radical groups and at the same time moderate groups in Indonesia contested through print media; whether it is owned by religious organizations, or national media that provides a column of opinions where the outside community can contribute their thoughts. Syamsul Rizal's research identified several magazines / print media that had affiliations with radical groups. For example; Sabili, Ummi, Annida, Tarbawi, Saksi, ${ }^{10}$ Arie Styaningrum Pamungkas also conducted a similar research on several radical media in Indonesia that were disseminated by radical groups. Unlike Rizal, Pamungkas is more specific about talking about the impact of "Ummi's da'wah media" in the process of constructing an understanding of Islamism and radicalism in Indonesia. ${ }^{11}$ In the national newspaper contestation which has more concern about the pattern and Islamic life in Indonesia such as Republika. Discourse related to radicalism can be more open compared to magazines that are made and published by themselves. The following are some of the contestations that occurred after radicalism emerged into open space in Indonesia in that period in the Republika newspaper.

There are two important ideas related to Islamic radicalism in Indonesia; first groups that calls on the government (as a regulator) to fight such movement because it would pose a serious threat to the condition of plurality in Indonesia, as well as the idea of the need for the re-actualization of values that did not have the motive of forced ideology to be understood. Second, a counterdiscourse that calls on the government not to juxtapose terrorists and radical attitudes with Islam. In this context, almost all Islamic dakwah media have the same tendency. The first groups are, for example the works of Rumadi, ${ }^{12}$

\footnotetext{
${ }^{10}$ Syamsul Rizal, "Media and Islamism in Post New Order Indonesia; The Case of sabili, Studia Islamika Vol 12 No 3 , 2005, 431

${ }^{11}$ Arie Setyaningrum Pamungkas, “The Dakwah Media in Post Soeharto Indonesia; From Politics Identity to popular culture; The Case of Ummi, Phd Thesis Universitas Berlin 2015.

${ }^{12}$ Rumadi, "Demokrasi dan Radikalisme Agama" in Surat Kabar Republika Jakarta, Edisi Kamis, 2 Juni 2002.
} 
Riza Sahbudi ${ }^{13}$, Umarudin Masdar, ${ }^{14}$ and Dawam Rahardjo. ${ }^{15}$ While from the second group, there are papers from Addian Husaeni and Isma'il Yusanto who defended Islamism from the frame of absolute universalism. That is, Islam cannot be identified with radical and explosive movements as broadcast in the context of terrorism in Indonesia. ${ }^{16}$

Contestation as I stated above, can only be accessed by a number of community groups. The spread of magazines and newspapers made by radical groups is certainly very minimal, community-based, and those who are interested in Islamic issues in Indonesia. Framing Islamism and how discourse contestation in newspapers, electronic media, and several other magazines are not as numerous as in Hidayatullah, Sabili, Republika, etc. Almost all national newspapers focus more on reporting on economic, political, and social conditions, as well as sports, which in segmentation of market share is more favored than raising ideas and Islamic contestations that have been debated time after time in Indonesia. Another possibility is that in the national newspapers and television, the editors are more aware of the importance of the idea of multiculturalism, pluralism and tolerance, rather than framing the importance of Islamic-based life in Indonesia.

In the second period, the period that has begun to change from the print tradition to virtual and online based. This seems to make the government and other elements of society who are anxious about the existence of radical groups begin to think to find ways to anticipate it. The researchers have also shifted from a large paradigm to a more post-modernist tradition, where one postulate is framed in certain conditions and realities. It is almost impossible to generalize what websites created by these radical groups are identified to automatically have affiliations with certain groups. In fact, as explained by the Ministry of Communication and Information of the Republic of Indonesia, starting from the beginning of 2010 there have been 814,594 sites contending the call for radicalism blocked by the government. ${ }^{17}$ After the 2008 ITE Law was passed, the government did not hesitate to publish to the public to be

\footnotetext{
${ }^{13}$ Riza Sihbudi Islam, "Radikalisme dan Demokrasi," in Surat Kabar Republika Jakarta, Edisi Kamis, 23 September 2004.

${ }^{14}$ Umaruddin Masdar, "Globalisasi dan Radikalisasi Massa" in Harian Pagi Republika Jakarta, Edisi Jumat, 04 Juli 2003.

${ }^{15}$ M. Dawam Rahardjo, "Fatwa MUI Cermin Radikalisasi Syariat Islam," in Harian Pagi Republika, Edisi Jumat, 20 Desember 2005.

${ }^{16}$ Adian Husaini, "Simpang Siur Radikalisme," in Harian Pagi Republika Edisi Jumat, 01 Desember 2005.

${ }^{17}$ See also that the Kominfo has blocked the sum of 814.594 sites. https://kominfo. go.id/index.php/content/detail/5083/Kominfo+Sudah+Blokir+814.594+Situs+Radikal+/0/ sorotan_med (retrieved on 21 Nopember 2017)
} 
more self-aware in rsponding radical sites in Indonesia. ${ }^{18}$ The government's assertive attitude towards radical groups shows that the existence of radical sites began to disrupt the stability of Muslims in Indonesia, as well as escalating dynamics of the national politics.

The government explained that the blocking was carried out because of the content with nuances of resistance to the government, an invitation to jihad against the government, and a distortion of the Pancasila ideology that had been agreed upon by a pluralistic Indonesian society. In this context, the government did not fight against Islam, but rather the Islamic groups who began inviting ways of treason against the state. However, what is unique is perhaps in the era of democracy, taking sides which has been demonstrated by the government as previously discussed, is not necessarily acceptable to the people of Indonesia. The battle ideas reappeared to adorn the debate on partiality. The general trend is that first, radical group sites have framed government policy as an arrogant and anti-democratic form of democracy. Second, the government treatment is considered part of a political strategy to eliminate Islam. Third, the government treatment is anti-Islamic and supports the secular paradigm. And the most interesting thing is that whatever the problem and policy made by the government, they always offer an Islamic system and an Islamic state as a solution to their readers. In fact, they did not argue whether the Islamic system offered provided space for freedom of expression as democracy implanted in the values of its government.

The last is the millennial era where the government has to work extra to be able to stem radicalism and how they spread radical ideas. The era where all media can be created, privatized, then distributed without people being able to monitor simultaneously. In this era, the existence of websites, blogs, and other online media products, has been linked to private space like BBM, Twitter, WhatsApp, telegram, and Facebook. In this private room, as a rule of thumb, the provider is very guarded. No one can manage this space, unless they make it. Recently, the government asked the owner of the Telegram social media to give the government access in order to be able to observe radical groups on their sharing channels. ${ }^{19}$ Like it or not, telegram provides some features that are timed and can disappear without the government's knowledge (secret chat). According to the government, the telegram channel also provides content that has nuances of radicalism, terrorism and calls to assemble bombs. ${ }^{20}$ In

\footnotetext{
${ }^{18}$ See also that the Kominfo BNPT asks for the ban of 22 sites https://kominfo.go.id/ index.php/content/detail/4627/BNPT+Minta+Kominfo+Blokir+22+Situs+Radikal/0/berita_satker (retrieved on 21 Nopember 2017)

${ }^{19}$ https://news.okezone.com/read/2017/07/16/337/1737475/telegram-diblokir-jokowi-kita-sudah-lama-amati-dan-ini-demi-keamanan-negara

${ }^{20} \mathrm{http}$ //tekno.kompas.com/read/2017/07/14/20495927/ini-alasan-pemerin-
} 
privatized spaces like this, reframing what is actually spread by radical groups is no longer easy. What is certain is that they voiced themselves for jihad against the government, jihad against the West and American antagonism, and other ideological content, as already described in the general character of radical movements in Indonesia.

\section{RESULT AND DISCUSSION}

Apart from the dimensions of political strategy, debates on social media, to mainstream media, between Islamic groups to fight the political power of Ahok, there is a topic that will actually be discussed more in this study, namely the call for jihad to fight religious enemies and jihad for the Unitary State of the Republic of Indonesia. Jihad against religious enemies because of the momentum of Rizieq Shihab's speech at the second 212 demonstration (February 21, 2017) in front of the Parliament's office. The speech was actually a common occurrence in radical Islamic circles, especially for the Islamic Defenders Front. ${ }^{21}$ However, the unique thing is what it really means by defending the Unitary State of the Republic of Indonesia in the frame of this radical group. Are they going to present Islam as a political system, or just call the substantive norms of Islam become the basis of the process and basis for determining the existing policies in Indonesia. ${ }^{22}$

Other facts related to radical groups and the Unitary State of the Republic of Indonesia, such as FPI, FUI, and other groups that still consider that the the Unitary State of the Republic of Indonesia need not be changed are available on the official website of the Islamic Defenders Front. (http://www. mozaikharokahfpi.com/search/label/Politik) and official habibrizieq.com (although in the process of this research, the site has been blocked / hacked, because it was inaccessible). These pages clearly state that they want to defend the Unitary State of the Republic of Indonesia (NKRI) from liberalism, ${ }^{23}$ communism, ${ }^{24}$ and foreign imperialism. ${ }^{25}$ On the other hand, the activities of this group are not in accordance with the ethical patterns that exist within the framework of the Unitary State of the Republic of Indonesia. They tend to

tah-blokir-telegram

${ }^{21} \mathrm{http}: / /$ www.voa-islam.com/read/indonesiana/2013/02/26/23405/wawasan-kebangsaan-habib-rizieq-soal-nkri-dan-gerakan-separatisme/\#sthash.8wNOayNJ.7cyUCJr4. dpbs

${ }^{22}$ http://www.voa-islam.com/read/indonesiana/2014/06/06/30786/habib-rizieqperda-syariat-sejalan-dengan-konstitusi-nkri-ideologi-pdip-anti-islam/

${ }^{23} \mathrm{http}: / /$ www.mozaikharokahfpi.com/2015/09/fpi-dengan-dukungan-penuh-kopassus-dan.html

${ }^{24}$ http://www.mozaikharokahfpi.com/2015/08/pernyataan-sikap-dpp-fpi-terhadap. html

\footnotetext{
${ }^{25}$ http://www.mozaikharokahfpi.com/2015/07/ada-israel-di-tolikara.html
} 
use anarchic methods to uphold their beliefs. They are also very concerned about the issue of defamation and the existence of religion, especially Islam. Moreover, they also pay attention to what is done by campus activist groups who tend to have Western thoughts, and so on.

In this light, it is not wrong then if the government and several regional heads urge FPI to continue to work on the whole the Unitary State of the Republic of Indonesia. For example, at the 19th FPI anniversary event Aneis Baswedan congratulated and hoped that FPI could maintain the integrity of the Unitary Republic of Indonesia and the diversity that has existed in Indonesia. ${ }^{26}$ The coverage by hidatullah.com also gave the title "Affirm the commitment to protect the the Unitary State of the Republic of Indonesia, FPI held the 19th Anniversary and the Commemoration of the Republic of Indonesia's Anniversary. ${ }^{27}$ Or the coverage by merdeka.com is similar; the headline used is that FPI will guard the NKRI from divisive groups. ${ }^{28}$ Even so on the official FPI website, they made a title that was more interesting, they mentioned that FPI celebrated the anniversary and at the same time committed to maintaining the integrity of the the Unitary State of the Republic of Indonesia. ${ }^{29}$ And there are still many other reports that mention similar patterns related to the relationship between FPI and the Unitary State of the Republic of Indonesia.

Different on official pages, or in other radical Islamist groups, national media often frames FPI and some groups uphold Islamic sharia without changing the NKRI (Unitary State of the Republic of Indonesia) into an Islamic state, as an anti-NKRI group. This is because what is disclosed and implemented in the form of action does not apply equally. For example in several cases FPI carried out activities that "violated" compliance as citizens against existing constitutions; insulting Pancasila, ${ }^{30}$ cross out the red and white flag, ${ }^{31}$ refused the construction of houses of worship of other religions, ${ }^{32}$ or the rejection of groups that do not agree with them through anarchic means. Therefore, portraits and slogans campaigned and endorsed by political actors on the bhinekaan

${ }^{26} \mathrm{https} / / / w w w . a n t a r a n e w s . c o m / b e r i t a / 647554 / a n i e s-m i n t a-f p i-j a g a-n k r i-d a n-k e-$

${ }^{27}$ https://www.hidayatullah.com/berita/nasional/read/2017/08/19/121780/teguhkan-komitmen-jaga-nkri-fpi-gelar-milad-ke-19-dan-peringatan-hut-ri.html

${ }^{28} \mathrm{https}$ ://www.merdeka.com/peristiwa/fpi-kami-akan-jadi-garda-terdepan-jagankri-dari-kelompok-pemecah-belah-bangsa.html sus-dan.html

${ }^{29} \mathrm{http}$ ://www.mozaikharokahfpi.com/2015/09/fpi-dengan-dukungan-penuh-kopas-

${ }^{30} \mathrm{http}: / /$ www.hukumonline.com/berita/baca/lt581324d499b3f/dinilai-menghina-pancasila--ketua-fpi-dilaporkan-ke-bareskrim

${ }^{31} \mathrm{http}: / /$ news.liputan6.com/read/2833684/polisi-pembawa-bendera-dicoret-tersangka-dan-simpatisan-fpi

${ }^{32} \mathrm{http}$ ///www.beritasatu.com/megapolitan/421380-ini-alasan-massa-tolak-pembangunan-gereja-santa-clara.html 
existence of FPI wanting to keep the the Unitary State of the Republic of Indonesia needs reinterpretation. This seems like the lips service of FPI leaders in order not to be the main opponent of the government.

The same pattern is also true for other radical groups, if one looks at what appears in cyberspace coverage. The Prosperous Justice Party (PKS) which is the accomplice of the transnational movement, Hizb ut-Tahrir Indonesia, and several other groups that play the political stage as models of their movements, often mention that NKRI is final. NKRI has become the result of joint ijtihad which cannot be contested. The following is some news related to PKS supporting the NKRI; republika.co.id "PKS initiates the Integrity of NKRI"33, on the party's official website, "PKS Legislator, NKRI is Undisputed" ${ }^{34}$ and "PKS shows a sense of nationalism and NKRI is undisputed" ${ }^{35}$. This is the case with Hizb ut-Tahrir Indonesia (HTI), which today is on the verge of dissolution by the government. On various occasions, the chairman of HTI has always emphasized that HTI activities are not in conflict with the Pancasila and NKRI, ${ }^{36}$ HTI contributes to strengthening the Unitary State of the Republic of Indonesia by educating the public, ${ }^{37}$ and HTI only provides ideas for discussion to find the best format for the Republic of Indonesia. ${ }^{38}$

From this fact it is clear that calls of anti-Pancasila, the Unitary State of the Republic of Indonesia, and Bhinneka Tunggal Ika (Unity in Diversity) are only made in closed spaces. They do not declare themselves as a group that wants to establish a different system with four national pillars in Indonesia. Occasionally they did not agree on Pancasila, the 1945 Constitution, and the diversity that existed in Indonesia, but they still wanted to take refuge behind the term of the Unitary State of the Republic of Indonesia. Or conversely, they doubted the existence of a unitary state system (republic), but still acknowledged the diversity that existed in Indonesia as an authentic form and destiny of the Almighty. Moreover, it must be admitted, the diction and logos that they use in political contestation are indeed more often hypocritical, just to get support from the plural Indonesian society. They did not hesitate to claim to be the most nationalist and supporters of the Republic of Indonesia if

${ }^{33}$ http://www.republika.co.id/berita/gaya-hidup/trend/17/05/03/en/islam-in-archipelago/13/11/21/nasional/daerah/13/10/30/mvh5rm-pks-sulut-keutuhan-nkri-harga-mati

${ }^{34} \mathrm{http}: / / \mathrm{pks} . \mathrm{id} /$ content/legislator-pks-nkri-harga-mati

${ }^{35}$ http://www.pkskabsmg.id/2017/10/09/kader-pks-tunjukan-sikap-nasionalisme-yang-tinggi-nkri-harga-mati/

${ }^{36} \mathrm{https}$ //nasional.tempo.co/read/873786/disebut-usung-konsep-khilafah-di-indonesia-ini-pengakuan-hti

${ }^{37} \mathrm{https} / / /$ nasional.sindonews.com/read/1203734/13/ismail-yusanto-kegia-

tan-hti-tak-bertentangan-dengan-pancasila-1494310247

${ }^{38} \mathrm{http}: / /$ www.tribunnews.com/nasional/2017/05/09/hti-bantah-tudingan-tidak-punya-kontribusi-bagi-negara 
they were already in a state of political contestation. Or, this is just an anecdote on social media, these radical groups are impromptu nationalist groups. Suddenly nationalists after being suspended, suddenly nationalists after being disbanded, were suddenly nationalist after their followers were abandoned.

As explained above how radical groups wrap up their political movements in the online media space. The simple thing to translate is that they show Islamic symbols as part of their struggle. In addition, hey do not display treason efforts as often directed at them. They, in my one-sided perspective, play the role of Islamism on the the Unitary State of the Republic of Indonesia frame. So, in this way, their existence cannot be rejected by all groups in Indonesia, especially Muslims. Perhaps it will be a little different if the Islamic features they use exactly the same as the covert ideology they indoctrinate to all members of the organization. For example they use different names than the origin of their group. The callers' association of Jihad against religious opponents is the National Movement for Guarding the Fatwa of the Indonesian Ulema Council (GNPF MUI). They are separated from one institution and side by side with the religious authority in Indonesia.

In addition to hiding some of the radical ${ }^{39}$ characteristics of the group, they also played with the sentiment of Muslims through a very provocative diction. For example, jihad, infidels, religious opponents, and Chinese. The word jihad, in the Islamic tradition is an attitude of sincerity to defend religion. The word jihad also has implications for sacrifices that have no limits for those who have the power to do it. The word jihad also means warfare to those who persecute society. And, what is shown in the Jakarta regional election, Ahok is often illustrated as a very anti-Islamic figure, ${ }^{40}$ Ahok interpreted the scriptures of others, and Ahok evicted poor Muslims in Jakarta and collaborated with Chinese people who have more capital to build grand buildings in Jakarta. And there are still many other issues framed by this radical group. Therefore, the simple answer to the question why it was viral on social media, because they played with the sentiment and sense of ownership of Muslims in religion which is believed to be true.

In addition, they also categorized Ahok as an infidel. The infidels in the Islamic dictionary are indeed prohibited from being a leader. The word kafir is "the enemy" of the Prophet Muhammad when leading Islam. The word Kafir is a word intended for anyone who is hostile to Islam. And, it must also be realized that, the prohibition of an infidel as a leader is certain (qath'i). As

${ }^{39}$ Atmaja (2016) provides a discussion of the ambiguous terminology of what is so called terrorism. This might be true for the case of the terminology of radicalism as well.

${ }^{40}$ https://www.eramuslim.com/berita/nasional/heboh-ahok-melarang-sembelih-kurban.htm 
for the debate of Muslim scholars, in a space far from the crowd related to the Kafir interpretation, it seems that it cannot be accepted by the majority of Indonesian people who have experience in religious education in a very rural environment. Therefore, when the word Kafir is identified with Ahok, there is no other reason to see the true side of Ahok; Ahok is a non-Muslim. Moreover, when Ahok had to face the verdict as a person who defamed Islam by the Religious Decision of the Indonesian Ulema Council (MUI), the MUI Deputy Secretary General Tengku Zulkarnain defined Ahok as a person to fight against and his blood is permitted to kill, in the dialog at the Indonesian Lawyer Club.

On the other hand, Ahok is a non-Indigenous person. Ahok comes from ethnic minorities, but has a history of dominating the economic sphere in Indonesia. So clearly, people's sentiment against the figure of Ahok can be framed from these various aspects. Ahok can be drowned out through the issue of religion-based, because he is practicing blasphemy, and this is still a living conflict that has no base in Indonesia. Ahok is also a figure of ethnic Chinese descent who has a dark history in Indonesia, and Ahok also has conflicttual political communication and no-compromise attitude when dealing with other political actors. ${ }^{41}$

Finally, this is perhaps very subjective, but it can be verified. The Ahok factor and the strengthening the attitude of conservatism and Islamism in the world, as well as the moral support provided by the MUI, and there is one more namely the Team Buzzer and the Media Center of the Political Parties of all parties who contested in the Jakarta Regional Election, have contributed to such contestation. For political observers, social media, and young people, today's cyber war is definitely supported by trained Human Resources. The Media Center Teams of each candidate can play various social media accounts in one hand. They can make tranding topics using robotic accounts and networks that they have. In my observation, all social media teams in the Jakarta regional election played like they were fighting in the real sense. It was obvious how the three candidates' hash-tags appeared when the debate took place in the Election process. In my opinion, all these elements provide a very strong slender for why the issue of jihad against religious issues can hit the social media.

There are two effects of Islamic radicalism preaching that took place in the Jakarta Election: First, the impact on the internal Muslims themselves. Second, the external impact on the integrity of the Unitary Republic of Indonesia

${ }^{41}$ For further information about Ahok profile's, see Rudi Valinka, A Man Called Ahok: Sepenggal Kisah Perjuangan \& Ketulusan (Kurawa: 2016). 
based on Pancasila, Bhinneka Tunggal Ika, and the 1945 Constitution. In the first part, radical groups' propaganda through social media has implications for demystification of Islamic teachings and figures who support Ahok in the post-conflict local election era. that is. For example, how pluralist figures such as Syafii Maarif, Said Aqil Siradj, Musthofa Bisri, Nadirsyah Husen, and Ahmad Sahal were identified with groups who did not understand Islam correctly. In fact, everyone knows, these Islamic thinkers have very much work and contributions in terms of moderate Islamic attitudes in Indonesia. Radical groups have succeeded in drawing lines of demarcation, which ones are truly Islamic, and which groups whose Islam is defeated by tolerant and westernized attitudes.

In addition to moderate Islamic figures, this line of demarcation has finally stunned young people in this moderate group. Because they are still young, the attitude they take is different from that of their neighbors who are wiser in acting. Moderate and radical group battles are very visible; such as the rejection of Banser and Ansor against Habib Riziq in Bangil Pasuruan, Rejection of Felix Shauw and Basallamah in Surabaya, and many other actions which were a reaction to the demystification of radical groups to kyai who became role models in the Nahdliyin in particular. In addition, the Nahdlatul Ulama youths are in fact also very creative in conducting cyber-war. They duplicate sites that have Islamic radicalism to make it more tolerant. They create blogs, twiter accounts, and Facebook fanspage to counter-fight radical groups who have already done so.

As for the external impact, of course, disharmony in the harmony of religious people. The discriminatory treatment of Ahok finally has an impact on the rejection of Radical-Islamic figures in areas where the majority are Christian or other religions. There are many facts of rejection of these radical groups in several regions, in Bali for example, or the strict rejection of the Dayak community against Tengku Zulkarnaen in Sintang. and several other regions. In fact, in the analysis of Idrus Al Hamid, the Jakarta effect also approached Jayapura, Manado, and Ambon Maluku. In areas with a majority that are not Muslim, they begin to think about how they also want to make rules so that prospective regional leaders must have the same religion as the majority of the religious communities around them. Of course, this has become very counterproductive to the patterns of religious harmony that have long been built in Indonesia. It is counter productive to tolerant and moderate symbols developed by the government.

There are four important concepts in discussing the thoughts of Antonio Gramsci; culture, hegemony, intellectualism and crisis. In the cultural position, 
Gramsci talks about how the ruling group plays its role, or it can lose its power. In this cultural position, also, the war of position and war of maneuvers are defined by Gramsci. In this context, according to Gramsci, a large group that has a strong role in forming and developing a cultural value system of a country can be defeated by attitudes and maneuvers carried out by militant groups. He gave an example of how the hegemonic dogma carried out by the designers of the power of Global capitalism could be defeated by communist groups in Russia. For Gramsci, a regulation and a search for strategic positions is very important to form the supra-structure of culture in a particular country. Stave Jones concludes Gramsci's view as follows:

"..the notion that the economic base determines the operations of an ideological and cultural superstructure. He proposes instead that we see the relationship between base and superstructure as a reflexive and dynamic one. Within this formation, he isolates civil society as having a key intermediary role and proposes that both conservative and transformative projects attempt to occupy consciousness and everyday life through the functioning of a civil society created in their service. To change society involves a protracted period of negotiation carried out in all the institutions of society and culture....since it involves elaborating subaltern and subordinate elements into a broader cultural and political project without dismissing their cultural distinctiveness." ${ }^{42}$

This quote means that a cultural value and ideology of a nation will continue to run dynamically, not statically. He is different from thinkers such as Althusser and Karl Marx who consider that the cultural space is influenced by piloting ideology and capitalism that play behind a nation's ideology. For Gramsci, an ideology will continue to be dialectically based on the supracultural forces in society. This belief is the one that was found behind the phenomena with radical preaching which overcame a long discourse on moderatism, liberalism, pluralism and tolerance in Indonesia. The Indonesian society has returned to an era where ideology of religion and Indonesian-ness is contested through hidden strategies. They, the radical groups, are very well aware of not being able to bring up the issue of anti-nationalism in front of Indonesian society, but can bring Radical Islamism into a political contestation in Indonesia, especially in a democratic society. This is in line with the theoretical assumptions developed by Greg Fealy and Anthony Bubalo which stated that democracy has a dual role; giving freedom to act, while providing space for developing conservatism and fundamentalism, so that they can rein

${ }^{42}$ Stave Jones, Antonio Gramsci, (Madison Eve, New York: Routledge, 2006), 99. 
in the condition of society in Indonesia. ${ }^{43}$

The nest is hegemony. Theoretically Gramsci defines hegemony, as quoted by Steve Jones as follows:

"Instead of seeing the economy as determining culture and politics, Gramsci argues that culture, politics and the economy are organized in a relationship of mutual exchange with one another, a constantly circulating and shifting network of influence. To this process he gives the name hegemony and ..... how hegemony differs fundamentally from domination. Seeing hegemony as a dynamic process militates against the view that students of culture can understand the meaning of a text in isolation. In this sense, asking you to analyse a single participatory programme was mildly disingenuous, since no one representation can capture the nexus of power at any one moment - it is indeed, for Gramsci, precisely not something that one can pin down since it is always 'in the process of becoming". ${ }^{4}$

It means that Gramsci interprets the word Hegemony instead of focussing on domination and the pressures made by certain groups or social classes. However, the word hegemony means a dynamic on-going processes which can be done in several ways and enforcement. Hegemony, according to Gramsci has many factors and variables that can be analyzed, not always dominated by aspects of politics, economy, and culture. The basis of Gramsci's epistemology in this hegemony can be assumed to originate from the concept of consciousness. A new knowledge or ideology or belief that is put in disguise, habituation and implementation (doctrination) into the atmosphere of the collective-mass consciousness, giving rise to a relatively new awareness. The source of knowledge possessed by individuals in a group, is not always easy to guess its origin, but it could be that awareness and knowledge that have been settling in society is a hegemonic program instilled by certain group subjects.

Hegemony refers to the notion of a socio-political situation which in Gramsci terminology is called a moment, where philosophy and social practices are united in a balanced state. Domination is the concept of reality which spreads through society in an institution and individual manifestations. The influence of this spirit is in the form of morality, customs, religion, political principles and all social relations, especially from the intellectual. Hegemony is always related to the state as a dictator class. ${ }^{45}$ Gramci changed the meaning of hegemony from strategy which, according to Lenin, becomes a concept like 2007), 78

${ }^{43}$ Greg Fealy dan Anthony Bubalo, Jejak Kafilah, terj, Akh. Muzakki (Bandung: Mizan,

${ }^{44}$ bid. 78.

${ }^{45}$ Ibid., 90. 
the Marxist concept of power and relations of production, class and state, and also becomes a means to understand society in order to change it. He develops ideas about leadership and their implementation of hegemony. A social group can even have to exercise leadership before seizing power of government (this is clearly one of the main requirements for obtaining that power); such readiness, in turn, becomes very important when the group exercises power, they must constantly "lead".

This concept of hegemony can be traced through Gramsci's explanation of class supremacy. According to him, the supremacy of a group manifests in two ways: domination and intellectual leadership. Hegemony refers to the strong influence of leadership in moral and intellectual form, which forms a classled attitude. This becomes a consensual image. The consensus that occurs between these two classes is created through coercion and covert influence through knowledge spread through the apparatuses of power. In other words hegemony is a chain of victories obtained through a consensus mechanism rather than through oppression of other social classes. Basically, hegemony is an attempt to lead people to assess and view social problems in a defined framework. ${ }^{46}$

Practically, according to Gramsci, one can gain hegemony through three processes of internalization as follows; first, identity, which is a locus that is pinned to someone, whether it is a form of profession or someone's psychological nature. Second, representation, i.e. a person must be able to represent another person's anxiety and similarity that will be influenced by his subconscious. Third, institutionalization, namely the institutionalization process of ideas and identities that have been read before. Therefore, if one looks at what happened in Jakarta, the fight and stakes of whose identity is the most Islamic and not full of Islam is carried out by radical groups in launching their preaching. They also represent the group from all elements, for example; there are Islamists from Nahdlatul Ulama ', as is often stated, following $\mathrm{KH}$. Ma'ruf Amin who is in fact the Chairperson of NU's Syuriah. Din Syamsudin and Amin Rais from Muhammadiyah, as well as other Islamic groups who could be moderate, were not radical. Even nationalist groups cannot escape the representation of their groups; there are figures such Prabowo Subianto, Kivlan Zein, and several retired high ranking military officers who seem to be under the strengthening of Islamism in Indonesia. They also called on the MUI as an institutionalization of their ideas and ideas.

Next is intellectualism. For Gramsci intellectualism is an important tool in carrying out hegemony or winning ideological or cultural settings. In his book

\footnotetext{
${ }^{46}$ Peter Mayo, Gramsci and Educational Thought (Oxford: Wiley Blackwell, 2010), 23.
} 
Prison, Gramsci defines what he means by intellectualism in social functions; "distinct social category independent of class is a myth. All men are potentially intellectuals in the sense of having an intellect and using it, but not all are intellectuals by social function. Intellectuals in the functional sense fall into two groups. In the first place there are the "traditional" professional intellectuals, literary, scientific and so on, whose position in the interstices of society has a certain inter-class aura about it but derives ultimately from past and present class relations and conceals an attachment to various historical class formations. Secondly, there are the "organic" intellectuals, the thinking and organizing element of a particular fundamental social class. These organic intellectuals are distinguished less by their profession, which may be any job characteristic of their class, than by their function in directing the ideas and aspirations of the class to which they organically belong." ${ }^{47}$

In the Jakarta regional elections, Eep Syaiful Hidayat, Yunarto Widjaya, and several branding teams of candidates who have the ability to read voter tendencies and Islamic attitudes in Indonesia which can be used by intellectual groups that seek to play the issue of diversity becomes viral in the media. Such accurate analysis, of course, cannot be done by just anyone. Even by Muslim intellectuals themselves. We can still remember that after the Jakarta Election, Syafii Maarif targeted successful teams of certain candidates who collaborated actively with radical groups in Jakarta. On the same occasion, one of the successful teams responded to the statement of concern by demonstrating strategic steps to reconnect religious conflicts in Jakarta. He gave an example of how at first Jokowi and Prabowo contested, but soon their relationship improved, forming Indonesian reconciliation faster than predicted.

The last of the processes of defining Gramsci's theory is crisis. For Gramsci the existence of a crisis is also an important factor in practicing hegemony. $\mathrm{He}$ said that:

"In every country the process is different, although the content is the same. And the content is the crisis of the ruling class's hegemony, which occurs either because the ruling class has failed in some major political undertaking for which it has requested, or forcibly extracted, the consent of the broad masses (war, for example), or because huge masses ... have passed suddenly from a state of political passivity to a certain activity, and put forward demands which taken together, albeit not organicall formulated, add up to a revolution. A 'crisis of authority' is spoken of: this is precisely the crisis of hegemony, or

${ }^{47}$ Antonio Gramsci, Selection From The Prison Notebook, Quintin Hoiare dan Nowell Smith (ed), Internasionale, Pullisher New York, 2000. 105. 
general crisis of the State." ${ }^{48}$

In this case, from my point of view, the demonstration of binding and the playing of social media is an attempt to carry out illegal acts on the authority of the state so as to create a crisis of trust in the government. The government itself has made many efforts to form a different movement pattern. ${ }^{49}$ However, the government maneuvers and political movements would not be able to stop what happened in Jakarta. Jakarta has become a vortex of the power of Radical Islamism, the stage of intolerant groups, and gained the power legitimacy of the Indonesian Ulema Council as a representation of Muslims in general. ${ }^{50}$

Basically, in my opinion regarding the dynamics of the Jakarta Election, the use of the term Jihad against religious enemies, and political branding that radical groups maintain the integrity of the the Unitary State of the Republic of Indonesia is a hegemonic form used to defeat the power of the moderate, tolerant and plural Muslim culture. They, along with the intellectual actors behind them, realize that to gain the legitimacy of religious power, they must collaborate with MUI (the fatwa institution in particular), then play social media card to invite all to participate, counter discourse either through their own online media or become resource persons in the national media. ${ }^{51}$ After that, they share with politicians who have an interest in advocating for ideas that are initiated. Finally, they use symbolic slogans with Islamic nuances to bring Muslims closer to the struggle they will carry out. This is similar to the pattern described by Masdar Hilmy regarding how radical groups carried out political-strategic resistance to the de-radicalization program launched by the government. Needless to say, that they did not carry out terrorist acts in the Jakarta Election contest.

\section{CONCLUSION}

In conclusion, radical propaganda became viral and draws attention of Muslims in Indonesia is caused by several factors; first, the political battle that presents identity politics in the country. Second, there is a shift in the

${ }^{48}$ Ibid, 192

${ }^{49}$ Compare to M. Husein Maruapey, "Penegakan Hukum dan Perlindungan Negara (Analisys Kritis terhadap Kasus Penistaan Agama oleh Patahana Gubernur DKI Jakarta," JIPSI: Jurnal Ilmu Politik dan Komunikasi, Vol 7, No 1 (2017), 28-29.

${ }^{50}$ Compare to Rahmatul Izad, "Fenomena Penistaan Agama dalam Perspektif Islam dan Filsafat Pancasila (Studi Kasus terhadap Demo Jilid II pada 04 November 2016," Jurnal Panangkaran, (Vol. 1, No. 2, 2017), 178-180. doi:https://doi.org/10.14421/panangkaran.2017.0101-10.

${ }^{51}$ S. Hamdi, "Conflicting Religious Identities: Blaspheming Islam and the Future of Democracy in Indonesia," Al-Albab, 6(2), (2017), 247 - 262. doi:https://doi.org/10.24260/alalbab.v6i2.778 
attitude of Islamism in Indonesia; from moderatism to conservativism. Third, the diction selected by using an Islamic symbolization approach which are literally Islamic teachings. Fourth, the support of the campaigning team and intellectual groups in the process of dissemination. There are two impacts resulting from this radical dakwah process; first, there was a de-mystification of religious leaders (especially those with moderate thought) and the division of Muslims in the grassroot. Second, the strengthening of the intolerant attitudes shown by Muslims and vice versa of non-Muslims in some regions.

Theoretically, the way we look at today's media cannot be immediately seen from mainstream journalism products, but it is also important to see mutualistic relations between social media, political actors, and intellectual actors who act play behind the news. At least, through such interpretation, it will produce a holistic understanding; including the politics of media owners. Practically, this research can be used as a basis for re-interpret how radical groups use the issue of saving the the Unitary State of the Republic of Indonesia as a hiding space from the ideology they want to display. The government needs to rethink how religion and identity politics should be presented in Indonesia, so that similar patterns are not copied by other regions in the country. The government, despite the fact that it has been done, need not be afraid to block the sites that provide calls for radicalism in Indonesia.

\section{BIBLIOGRAPHY}

Atmaja, D. (2016). The So-Called "Islamic Terrorism": A Tale of the Ambiguous Terminology. Al-Albab, 5(1), 105 - 122. doi:https://doi.org/10.24260/ alalbab.v5i1.419

Fealy, G. \& Bubalo, A. (2007). Jejak Kafilah, (Translatted by Akh. Muzakki). Bandung: Mizan.

Esposito, J. (2010). The Future Of Islam. New York: Oxford Univercity Press.

Gramsci, A. (2000). Selection From The Prison Notebook. (Edited by Quintin Hoiare \& Nowell Smith (ed). New York: Internasionale Publisher.

Hamdi, S. (2017). Conflicting Religious Identities: Blaspheming Islam and the Future of Democracy in Indonesia. Al-Albab, 6(2), 247 - 262. doi:https://doi.org/10.24260/alalbab.v6i2.778

Husaini, A. (2005). "Simpang Siur Radikalisme," in Harian Pagi Republika. Edisi Jumat, 01 Desember 2005.

Islam, R. S. (2004). "Radikalisme dan Demokrasi," in Surat Kabar Republika Jakarta. Edisi Kamis, 23 September 2004. 
Izad, R. (2017). "Fenomena Penistaan Agama dalam Perspektif Islam dan Filsafat Pancasila (Studi Kasus terhadap Demo Jilid II pada 04 November 2016," Jurnal Panangkaran. Vol. 1, No. 2, 2017. doi:https://doi. org/10.14421/panangkaran.2017.0101-10.

Jones, S. (2006). Antonio Gramsci. Madison Eve, New York: Routledge.

Junaidi, A. (2017). "Media dan Keberagaman: Analisis Pemberitaan Media Daring Seputar Pemilihan Kepala Daerah DKI Jakarta," Jurnal Muara Ilmu Sosial, Humaniora, dan Seni. Vol. 1, No. 1, April 2017.

Malik, A. (2016). "Agitasi dan Propaganda di Media Sosial (Studi Kasus Cyberwar Antar-Netizen terkait Dugaan Penistaan Agama oleh Basuki Tjahaja Purnama)," Jurnal Lontar, Vol 4 No 3 (September - Desember 2016).

Maruapey, M. H. (2017). "Penegakan Hukum dan Perlindungan Negara (Analisys Kritis terhadap Kasus Penistaan Agama oleh Patahana Gubernur DKI Jakarta," JIPSI: Jurnal Ilmu Politik dan Komunikasi, Vol 7, No 12017.

Masdar, U. (2003). "Globalisasi dan Radikalisasi Massa" in Harian Pagi Republika Jakarta. Edisi Jumat, 04 Juli 2003.

Mayo, P. (2010). Gramsci and Educational Thought. Oxford: Wiley Blackwell.

Muthohirin, N. "Mewaspadai Radikalisme Islam di Media Sosial," in Geotime. http://geotimes.co.id/mewaspadai-radikalisme-islam-di-media-sosial/

Pamungkas, A.S., (2015). “The Dakwah Media in Post Soeharto Indonesia; From Politics Identity to popular culture; The Case of Ummi. Berlin University: Unpublished Phd Thesis.

Pujiati, T. (2017). “Dakwah Radikal dan Propaganda Media Sosial," in http:// jalandamai.org/dakwah-radikal-dan-propaganda-media-sosial.html

Rahardjo, M. D. (2005). Fatwa MUI Cermin Radikalisasi Syariat Islam, Harian Pagi Republika. Jumat, 20 Desember 2005.

Rizal, S. (2005). "Media and Islamism in Post New Order Indonesia; The Case of sabili, Studia Islamika Vol 12 No 3.

Rumadi, (2002). "Demokrasi dan Radikalisme Agama" in Surat Kabar Republika Jakarta. Edisi Kamis, 2 Juni 2002.

Valinka, R. (2016) A Man Called Ahok: Sepenggal Kisah Perjuangan \& Ketulusan. Kurawa: 2016. 
Wahid, D. (2014). "Kembalinya Konservatisme Islam Indonesia," Studia Islamika. Vol. 21 No. 22014.

Yuwono, I. D. (2017). Gara-Gara Ahok dari Kegaduhan ke Kegaduhan. Yogyakarta: Media Pressindo. 